\title{
PENINGKATAN HASIL BELAJAR SISWA KELAS V DENGAN MODEL PEMBELAJARAN SAVI PADA MATA PELAJARAN IPA DI SDN MANGKUJAYAN I KABUPATEN PONOROGO
}

\author{
Naniek Kusumawati \\ naniek@unipma.ac.id \\ Pendidikan Guru Sekolah Dasar \\ Fakultas Keguruan dan Ilmu Pendidikan \\ Universitas PGRI Madiun
}

\begin{abstract}
The result of observation in state elementary school Mangkujayan I at learning process on 5th grade which is still conventional so student's mindset's development and creativity is less. There are some teachers especially 5th grade's teachers which only tell the learning material to the students and the students only listen, make a note and memorize the material. This study aims to improve student learning outcomes, especially on science subjects class V using SAVI learning model. This research uses classroom action research or CAR. This research procedure uses four steps of cycle such as planning, implementating, observing and reflecting step. Data collection technique is cognitive test and data collection instrument is test and observation instrument. Analysis of the data obtained shows that there is an increase in student learning outcomes that can be seen from the average percentage of the results in the first cycle is $65 \%$ which means there are 13 of 20 students who complete. There is $90 \%$ increasing on second cycle which means 18 of 20 students who can be succes on learning. Based on the research result, it can be concluded that the implementation of SAVI learning model can increase the study performance of students on natural studies of 5th grade of SDN Mangkujayan I.
\end{abstract}

Keywords: SAVI learning models, study performance IPA.

Abstrak: Berdasarkan hasil observasi yang dilakukan peneliti di SDN Mangkujayan I, diketahui bahwa proses pembelajaran di kelas $\mathrm{V}$ masih bersifat konvensional, sehingga kurang mengembangkan pola pikir dan kreatifitas siswa. Terdapat beberapa guru khususnya pada mata pelajaran IPA kelas V dalam mengajar hanya menggunakan metode ceramah dan siswa hanya mendengarkan, mencatat serta menghafalkan materi. Penelitian ini bertujuan untuk meningkatkan hasil belajar siswa khususnya pada mata pelajaran IPA kelas V dengan menggunakan model pembelajaran SAVI. Penelitian ini merupakan penelitian tindakan kelas (PTK), prosedur penelitian yang digunakan berupa siklus yang terdiri dari empat tahap yaitu tahap perencanaan, pelaksanaan, observasi dan refleksi. Teknik pengumpulan data yang digunakan adalah tes kognitif dan alat pengumpulan data yang digunakan adalah instrumen soal dan lembar observasi. Analisis data yang diperoleh menunjukkan bahwa terjadi peningkatan pada hasil belajar siswa yang dapat dilihat dari hasil persentase rata-rata pada siklus I yaitu 65\% yang artinya ada 13 dari 20 siswa yang tuntas. Terjadi peningkatan pada siklus yang ke II yaitu $90 \%$ yang artinya ada 18 dari 20 siswa yang tuntas dalam pembelajaran. Berdasarkan hasil penelitian, dapat disimpulkan bahwa penggunaan model pembelajaran SAVI dapat 
Naniek, Peningkatan Hasil Belajar Siswa...

meningkatkan hasil belajar siswa pada mata pelajaran IPA kelas V SDN

Mangkujayan I.

Kata Kunci : model pembelajaran SAVI, hasil belajar IPA

\section{PENDAHULUAN}

Keberhasilan proses pembelajaran tidak terlepas dari kemampuan guru dalam mengembangkan model-model pembelajaran yang berorientasi pada peningkatan intensitas keterlibatan siswa secara efektif di dalam proses pembelajaran. Model pembelajaran merupakan kerangka konseptual berupa pola prosedur sistematik yang dikembangkan berdasarkan teori dan digunakan dalam mengorganisasi proses belajar mengajar untuk mencapai tujuan mengajar (Sani, 2013: 89).

Pengembangan model pembelajaran yang tepat pada dasarnya bertujuan untuk menciptakan kondisi pembelajaran yang memungkinkan siswa dapat belajar secara aktif dan menyenangkan sehingga siswa dapat meraih hasil belajar dan prestasi yang optimal. Oleh karena itu sebagai guru juga harus bisa mengembangkan model-model pembelajaran. Oleh karena itu, agar dapat mengembangkan model pembelajaran yang efektif maka guru harus memiliki pengetahuan yang memadai berkenaan dengan konsep-konsep dan cara pengimplementasian model-model pembelajaran tersebut dalam proses pembelajaran.

Proses pembelajaran yang efektif memiliki keterkaitan dengan tingkat pemahaman guru terhadap perkembangan kondisi-kondisi siswa di kelas, dengan demikian pentingnya pemahaman guru sangat diperlukan terhadap sarana dan fasilitas sekolah yang tersedia, kondisi kelas dan beberapa faktor lain yang memiliki keterkaitan dengan pembelajaran. Tanpa pemahaman terhadap berbagai kondisi ini, model pembelajaran yang dikembangkan oleh guru cenderung tidak dapat meningkatkan peran serta siswa secara optimal dalam proses pembelajaran, dan pada akhirnya tidak dapat memberi sumbangan yang besar terhadap pencapaian hasil belajar.

Salah satu model pembelajaran yang di kenal adalah model pembelajaran SAVI (somatic, auditorry, visualization and intellectually). Dalam setiap pembelajaran hendaknya tercipta beberapa jenis kegiatan, baik itu mendengar, melihat sampai pada tahap mengkreasi sendiri sebuah karya dengan kemampuan yang dimiliki siswa. Karakteristik dalam model pembelajaran SAVI sudah mewakili semua aktivitas siswa di dalam kegiatan pembelajaran. Karena siswa tidak hanya mendapatkan pengetahuan saja, melainkan juga dapat memahami dan mengalami langsung tentang apa yang telah dipelajari. Model pembelajaran tersebut dapat dikatakan salah satu model pembelajaran yang dapat diterapkan untuk mengatasi permasalahan yang ada di SDN Mangkujayan I Kabupaten Ponorogo. Berdasarkan observasi yang dilakukan, selama ini belum ada yang menerapkan model pembelajaran tersebut di SDN Mangkujayan I, sehingga dengan adanya penerapan model pembelajaran ini dapat memberikan perubahan dalam 
Naniek, Peningkatan Hasil Belajar Siswa...

proses pembelajaran sehingga dapat meningkatkan hasil belajar siswa SDN Mangkujayan I kelas V khususnya pada mata pelajaran IPA.

Mengkaji dari permasalahan di atas, penulis mencoba untuk meneliti tentang penggunaan model pembelajaran SAVI dalam meningkatkan hasil belajar IPA siswa. Untuk itu penulis mengadakan suatu penelitian tindakan kelas (PTK) dengan judul "Peningkatan Hasil Belajar Siswa Kelas V dengan Model Pembelajaran Savi pada Mata Pelajaran IPA di SDN Mangkujayan I Kabupaten Ponorogo".

Berdasarkan latar belakang di atas, maka penulis dapat mengidentifikasi permasalahan-permasalahan yang terjadi dalam pembelajaran yang ada di SDN Mangkujayan I Kabupaten Ponorogo diuraikan sebagai berikut:

1. Proses pembelajaran masih bersifat konvensional.

2. Guru kurang maksimal dalam mengembangkan model pembelajaran yang inovatif.

3. Pembelajaran kurang mengembangkan pola pikir, keaktifan dan kreativitas siswa selama proses pembelajaran berlangsung.

4. Siswa hanya cenderung menghafalkan konsep-konsep yang telah diberikan oleh guru.

5. Belum menerapkan model pembelajaran SAVI.

Dilihat dari permasalahannya, maka penulis mengajukan rumusan masalah sebagai berikut, "Bagaimanakah Model Pembelajaran SAVI (somatic, auditory, visualization, and intelectually) dalam Meningkatkan Hasil Belajar IPA pada Siswa Kelas V SDN Mangkujayan I Kabupaten Ponorogo?"

\section{KAJIAN PUSTAKA}

Arends (dalam Trianto, 2014:54) mengemukakan bahwa model pembelajaran mengacu pada pendekatan pembelajaran yang akan digunakan, termasuk di dalamnya tujuan-tujuan pembelajaran, tahap-tahap dalam kegiatan pembelajaran, lingkungan pembelajaran, dan pengelolaan kelas.

Memilih istilah model pembelajaran berasarkan dua alasan penting, yaitu pertama istilah model mempunyai makna lebih luas daripada strategi, metode, atau prosedur. Kedua, model dapat berfungsi sebagai sarana komunikasi yang penting. Model pembelajaran dapat diklasifikasikan berdasarkan tujuan pembelajaran, sintaksisnya, dan sifat lingkungan belajarnya. Model pembelajaran yang dimaksudkan adalah model pembelajaran yang memiliki kerangka konseptual yang melukiskan prosedur sistematik dalam mengorganisasikan pengalaman belajar.

Menurut Sagala (2013:11) belajar merupakan komponen ilmu pendidikan yang berkenaan dengan tujuan dan bahan acuan interaksi, baik yang bersifat eksplisit maupun implisit (tersembunyi). Teori-teori yang dikembangkan dalam komponen ini meliputi antara lain teori tentang tujuan pendidikan, organisasi kurikulum, isi kurikulum, dan modul-modul pengembangan kurikulum.

Djamarah (2012:21) berpendapat bahwa belajar adalah suatu aktifitas yang sadar akan tujuan. Tujuan dalam belajar adalah terjadinya suatu perubahan dalam diri individu. Perubahan dalam arti menuju ke perkembangan pribadi individu seutuhnya. 
Naniek, Peningkatan Hasil Belajar Siswa...

Menurut Kusumawati (2013:2) pembelajaran SAVI adalah pembelajaran yang menekankan pada bermaknanya belajar melalui mendengarkan, menyimak, berbicara, presentasi, argumentasi, mengemukakan pendapat, dan menanggapi, serta menggunakan kemampuan berfikir (minds on) untuk meningkatkan konsentrasi pikiran melalui bernalar, menyelidiki, mengidentifikasi, menemukan, menciptakan, mengkrontruksi, memecahkan masalah dan menerapkan, sedangkan menurut Meire (2002:91) belajar menggabungkan gerakan fisik dan intelektual serta menggunakan semua indra yang tujuannya agar dapat mempengaruhi kemajuan belajar, merupakan pengertian dari belajar SAVI. SAVI merupakan akronim dari somatic, auditory, visual, and intelectual, yang memiiki arti belajar melalui pemanfaatan gerakan tubuh, (hands on, aktivitas fisik) dimana belajar dimaknai dengan "mengalami" dan "melakukan" untuk dapat mengaktualkan kemampuan analisis dalam memecahkan masalah.

\section{METODE PENELITIAN}

Penelitian ini menggunakan metode penelitian tindakan kelas. Menurut Arikunto, dkk (2009:2) penelitian tindakan kelas merupakan kegiatan penelitian yang dilakukan di dalam kelas. Penelitian tindakan kelas merupakan salah satu jenis dari pendekatan kualitatif yang dilakukan dengan bentuk siklus atau melingkar (cyclical), bukan linear seperti kuantitatif.

Data yang dikumpulkan adalah melalui catatan observasi dan hasil evaluasi yang dilakukan sejak awal siklus dalam proses penelitian ini. Catatan observasi digunakan untuk mengetahui peningkatan prestasi belajar siswa.

Jenis data yang digunakan dalam penelitian ini adalah data kualitatif, dimana dalam penelitian in, peneliti memperoleh data-data berupa keterangan informasi berupa lisan ataupun berupa tulisan. Dalam penelitian ini, yang menjadi jenis data penelitian adalah: 1) hasil observasi yang memuat aktivitas siswa maupun guru pada saat pelaksanaan pembelajaran.; 2) hasil belajar siswa pada latihan soal yang diberikan pada saat pelajaran IPA.

Sumber data dalam penelitian yang akan dilakukan adalah semua siswa kelas V SDN Mangkujayan I Kabupaten Ponorogo. Jumlah siswa yang akan diteliti sebanyak 20 siswa yang terdiri dari 6 siswa laki-laki dan 14 siswa perempuan. Penelitian ini dilakukan pada kelas $\mathrm{V}$ dikarenakan hasil belajar siswa dalam mata pelajaran IPA masih tergolong rendah karena di kelas ini pembelajarannya masih bersifat konvensional.

Instrumen penjaringan data yang digunakan adalah instrumen yang berupa soal tes kognitif yang berisi 20 soal pilihan ganda dan 5 soal uraian. Selain itu, data juga di peroleh dari hasil observasi dari guru maupun siswa itu sendiri. Hal tersebut dilakukan agar peneliti mudah untuk mengamati ada atau tidak adanya peningkatan baik dari hasil belajar maupun peningkatan dalam kegiatan pembelajaran. 
Naniek, Peningkatan Hasil Belajar Siswa...

\section{HASIL PENELITIAN}

Pada bagian ini, penulis akan menguraikan mengenai hasil penelitian dari hasil sebelum sampai pada siklus terakhir, ketuntasan nilai yang diperoleh pada siswa kelas V SDN Mangkujayan I mata pelajaran IPA dengan menggunakan model pembelajaran SAVI. Dari observasi yang dilakukan oleh peneliti, dapat diperoleh hasil penelitian dari ketiga siklus yang sudah diterapkan. Dalam penelitian ini di kegiatan pertama yang dilakukan adalah pra siklus. Pra siklus ini diawali kegiatan wawancara dengan guru kelas V mengenai pembelajaran IPA yang dilakukan selama ini. Selain itu, peneliti juga melakukan wawancara dengan salah satu siswa kelas V. Dari hasil wawancara yang dilakukan dengan guru dan siswa tersebut dapat ditarik kesimpulan bahwa di SDN Mangkujayan I ini pembelajaran masih bersifat konvensional. Guru hanya melakukan ceramah dalam kegiatan pembelajaran, sehingga dapat menyebabkan prestasi belajar siswa banyak kurang maksimal karena masih banyak siswa yang nilainya dibawah KKM 75. Pada pra siklus ini diperoleh nilai rata-rata siswa yaitu 61,75 atau sekitar $30 \%$ ketuntasan dari 20 siswa.

Pada tahap selanjutnya, peneliti melakukan penelitian siklus I. Hasil penelitian dari siklus I ini sudah mulai ada peningkatan walaupun masih tergolong sedikit. Pada siklus ini peneliti menerapkan model pembelajaran SAVI. Dalam pelaksanaannya siswa yang berani melakukan tanya jawab dengan guru hanya sebagian kecil saja, karena masih banyak siswa yang kurang memperhatikan ketika guru menjelaskan materi dan menerapkan media pembelajaran, sehingga menyebabkan nilai pada saat evaluasi masih banyak yang belum mengalami ketuntasan belajar. Akan tetapi pada siklus ini sudah mengalami peningkatan dari pembelajaran sebelumnya. Rata-rata nilai yang diperoleh yaitu $65 \%$ ketuntasan dari 20 siswa kelas V. Pada siklus ini kekurangan guru kurang memusatkan perhatian siswa pada saat kegiatan pembelajaran dan penerapan media pembelajaran sehingga masih ada sebagian siswa yang kurang aktif dalam kegiatan pembelajaran.

Selanjutnya yaitu pada tahap siklus II. Pada siklus ini guru menerapkan model pembelajaran SAVI berbantu dengan media pembelajaran berupa video. Dalam kegiatan ini aktifitas belajar siswa mengalami peningkatan yang signifikan dari pada pembelajaran yang sebelumnya. Seluruh siswa dapat memfokuskan perhatiannya selama kegiatan pembelajaran berlangsung utamannya pada saat pemutaran video cahaya banyak siswa laki-laki maupun perempuan aktif bertanya. Oleh karena itu, nilai pada saat siklus ke II ini nilai siswa pada saat evaluasi pembelajaran juga tergolong maksimal, hanya ada sebagian kecil yang belum tuntas dalam mengerjakan soal evaluasi. Rata-rata nilai dalam siklus ini sejumlah 82,00 atau 90\% dari 20 siswa yang tuntas. 
Naniek, Peningkatan Hasil Belajar Siswa...

\section{PEMBAHASAN}

Pada saat siklus I guru tidak memberikan penekanan kepada siswa bahwa siswa yang nilainya kurang harus menghafalkan dan menyebutkannya didepan kelas, sehingga masih banyak siswa yang kurang memperhatikan ketika guru memberikan penjelasan. Pada siklus II siswa lebih memperhatikan ketika guru memberikan penjelasan terkait materi cahaya, selain itu penggunaan media pembelajaran juga mempengaruhi hasil belajar siswa. Pada saat siklus ini menunjukkan hampir semua siswa memperhatikan dan mayoritas bisa melakukan tanya jawab dengan guru. Oleh karena itu terdapat peningkatan dari tiap siklus, hal tersebut dapat dilihat pada grafik perbandingan penggunaan model pembelajaran SAVI dari siklus I ke siklus II dapat dilihat pada tabel 5.4 .

Tabel 1. Perbandingan Hasil Belajar pada siklus I dan siklus II

\begin{tabular}{|c|c|c|c|c|}
\hline \multirow{2}{*}{ No. } & \multicolumn{2}{|c|}{ Siklus I } & \multicolumn{2}{c|}{ Siklus II } \\
\cline { 2 - 5 } & Skor & Ketuntasan & Skor & Ketuntasan \\
\hline 1 & 85 & $\mathrm{~T}$ & 95 & $\mathrm{~T}$ \\
\hline 2 & 75 & $\mathrm{~T}$ & 100 & $\mathrm{~T}$ \\
\hline 3 & 80 & $\mathrm{~T}$ & 80 & $\mathrm{~T}$ \\
\hline 4 & 70 & $\mathrm{TT}$ & 75 & $\mathrm{~T}$ \\
\hline 5 & 75 & $\mathrm{~T}$ & 95 & $\mathrm{~T}$ \\
\hline 6 & 70 & $\mathrm{TT}$ & 85 & $\mathrm{~T}$ \\
\hline 7 & 75 & $\mathrm{~T}$ & 85 & $\mathrm{~T}$ \\
\hline 8 & 70 & $\mathrm{TT}$ & 70 & $\mathrm{TT}$ \\
\hline 9 & 80 & $\mathrm{~T}$ & 85 & $\mathrm{~T}$ \\
\hline 10 & 65 & $\mathrm{TT}$ & 80 & $\mathrm{~T}$ \\
\hline 11 & 75 & $\mathrm{~T}$ & 80 & $\mathrm{~T}$ \\
\hline 12 & 75 & $\mathrm{~T}$ & 85 & $\mathrm{~T}$ \\
\hline 13 & 80 & $\mathrm{~T}$ & 80 & $\mathrm{~T}$ \\
\hline 14 & 75 & $\mathrm{~T}$ & 80 & $\mathrm{~T}$ \\
\hline 15 & 85 & $\mathrm{~T}$ & 85 & $\mathrm{~T}$ \\
\hline 16 & 65 & $\mathrm{TT}$ & 80 & $\mathrm{~T}$ \\
\hline 17 & 65 & $\mathrm{TT}$ & 60 & $\mathrm{TT}$ \\
\hline 18 & 80 & $\mathrm{~T}$ & 85 & $\mathrm{~T}$ \\
\hline 19 & 80 & $\mathrm{~T}$ & 80 & $\mathrm{~T}$ \\
\hline 20 & 70 & $\mathrm{TT}$ & 75 & $\mathrm{~T}$ \\
\hline$\sum$ & 15 & $\mathrm{~T}=13$ & 1640 & $\mathrm{~T}=18$ \\
\hline$\%$ & $\mathbf{7 4}$ & $\mathbf{6 5}$ & $\mathbf{8 2}$ & \\
\hline
\end{tabular}

Berdasarkan tabel 1 diketahui bahwa jumlah rata-rata skor tes pada siklus II mengalami peningkatan yang signifikan yaitu 82 poin dan daya serap klasikal adalah 90\% sehingga hasil belajar siswa telah mencapai ketuntasan belajar yang ditetapkan yaitu rata-rata $>75$ dan daya serap klasikal $90 \%$ hal ini disebabkan keaktifan siswa meningkat pada saat tanya jawab dan mengerjakan tugas individu. Siswa berani bertanya materi yang belum dipahami sebagai persiapan menghadapi kegiatan tanya jawab sehingga jumlah siswa yang tuntas belajar pada siklus II ini meningkat yaitu dari 
Naniek, Peningkatan Hasil Belajar Siswa...

20 siswa ada 18 siswa yang tuntas dalam kegiatan pembelajaran pada siklus II, sedangkan pada siklus I hanya ada 13 siswa yang tuntas .

Perbandingan tersebut dapat dilihat pada grafik berikut ini:

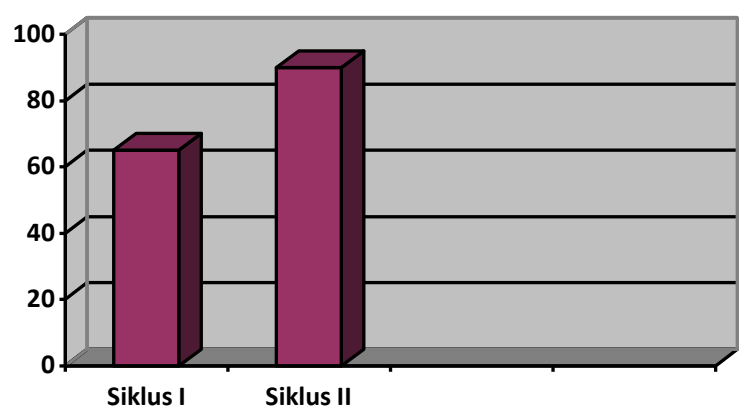

\section{Grafik 1. Ketuntasan Hasil Belajar Siswa pada Siklus I dan Siklus II}

\section{SIMPULAN}

Berdasarkan pembahasan hasil penelitian siklus I dan siklus II dapat disimpulkan bahwa Model Pembelajaran SAVI (somatic, auditory, visualization, and intelectually) Dapat Meningkatkan Hasil Belajar IPA Pada Siswa Kelas V SDN Mangkujayan I Kabupaten Ponorogo. Hal tersebut ditunjukan dengan presentase ketuntasan dari siklus I yaitu $65 \%$ menjadi $90 \%$ pada siklus II.

\section{SARAN}

1. Guru yang melaksanakan model pembelajaran SAVI hendaknya pandai memotivasi siswa, selain itu guru juga harus aktif membuatkan rangkuman pelajaran yang akan dipelajari siswa dan yang akan menjadi bahan pertanyaan guru.

2. Kepala sekolah diharapkan lebih memperhatikan kualitas mengajar guru dan memantau perkembangan hasil belajar siswa yang berdampak pada prestasi belajarnya.

3. Bagi peneliti lanjut diharapkan bisa memberikan koreksi dan saran mengenai penelitian ini karena peneliti merasa masih banyak kekurangan dalam pembuatannya. Selain itu, peneliti lanjut bisa mengembangkan model pembelajaran SAVI ini agar menggunakan media bantu yang lebih menarik lagi agar siswa lebih maksimal dalam kegiatan pembelajaran.

\section{DAFTAR RUJUKAN}

Arikunto, Suharsimi. 2009. Penelitian Tindakan Kelas. Jakarta: PT Bumi Aksara.

Djamarah, Syaiful Bahri. 2012. Prestasi Belajar dan Kompetensi Guru. Surabaya:

Usaha Nasional.

Kusumawati, Naniek. 2017. Pengaruh Model Pembelajaran Kooperatif Dengan

Snowball Throwing Terhadap Hasil Belajar IPA Pada Siswa Kelas IV SDN 
Naniek, Peningkatan Hasil Belajar Siswa...

Bondrang Kecamatan Sawoo Kabupaten Ponorogo Tahun Pelajaran 2016/2017. Jurnal Ibriez. Volume 02 Nomor 1 Tahun 2017.

Kusumawati, Sri Wahyuni, dkk. 2013. Model Pembelajaran SAVI untuk Meningkatkan

Ketrampilan Pemecahan Masalah.

http://ejournal.unesa.ac.id/article/5401/18/article.pdf. (di akses pada tangal 3 Maret 2016 pukul 15:43).

Sagala, Syaiful. 2013. Konsep dan Makna Pembelajaran. Bandung: Alfabeta

Sani, Ridwan Abdulah. 2013. Inovasi Pembelajaran. Jakarta: Bumi Aksara.

Trianto. 2014. Model Pembelajaran Terpadu. Jakarta:Bumi Aksara. 